
\title{
$\begin{array}{ll}\text { Research Square } & \begin{array}{l}\text { They should not be considered conclusive, used to inform clinical practice, } \\ \text { or referenced by the media as validated information. }\end{array}\end{array}$ \\ Determination of Streptomycin Residue in Imported and Locally Produced Honey in Kosovo
}

\section{Adem Rama}

Universiteti i Prishtines

Imer Haziri ( $\nabla$ imer.haziri@uni-pr.edu )

Universiteti i Prishtines

lliriana Miftari

Universiteti i Prishtines

Afërdita Zuka

Universiteti i Prishtines

Blend Zhuri

Universiteti i Prishtines

Arlind Latifi

Universiteti i Prishtines

Drilon Hasani

Universiteti i Prishtines

Fatgzim Latifi

Universiteti i Prishtines

\section{Research Article}

Keywords: Honey, Antibiotics, ELISA, Public Health, Kosovo

Posted Date: February 8th, 2022

DOl: https://doi.org/10.21203/rs.3.rs-1318821/v1

License: () (1) This work is licensed under a Creative Commons Attribution 4.0 International License. Read Full License 


\section{Abstract}

The objective of this study was to assess the occurrence of streptomycin residues of locally produced and imported honey collected from individual apiaries and retail markets during 2017 from six different regions (Gjilan, Mitrovica, Peja, Prizren, Prishtina, and Ferizaj) in Kosovo. In the present study, 155 honey samples have been qualitatively screened by enzyme-linked receptor-binding assays (ELISA). A descriptive statistic is used to provide the basic features of the sample and measure. In total, 45 (29\%) samples were positive, while 110 (71\%) were negative. Streptomycin residues were found in a considerable number of local honey samples, 34 out of $131(25.9 \%)$, and imported honey, 11 out of 24 samples (45.8\%), respectively. None of the positive samples has exceeded e maximum residue levels (MRL) stated by the European Union (EU) regulations. ELISA analysis demonstrated that streptomycin residues lie between $2.1-9.8 \mathrm{ng} / \mathrm{mL}$. Regarding the regional distribution of the positive samples, most of them were from Ferizaj and Prizren Region. Based on these results, competent authorities should establish and maintain continuous honey monitoring programs to ensure Kosovo consumers', risk-free honey. Besides, there is a pressing need for additional research to accurately assess other aspects of this problem and identify effective corrective actions designed to reduce honey bee contaminants.

\section{Introduction}

Kosovo has suitable conditions for beekeeping development such as climate, relief, and many honey-bearing plants that guarantee the production of good honey and beekeeping products (Panettieri 2013). Beekeeping is a viable business that significantly contributes to increasing and diversifying many rural households' incomes in Kosovo Ministry of Agriculture, Forestry and Rural Development (MAFRD. 2017). Beekeeping provides various benefits, such as income from the sale of bee products, self-employment opportunities, pollination, and biodiversity conservation. Currently, Kosovo has 6,453 beekeepers with 70,664 bee-hives distributed in Kosovo's territory, with average production for bee society $9.55 \mathrm{~kg}$ honey or $674 \mathrm{t} / \mathrm{yr}$. In contrast, the import in 2014 was around 140 t/yr Kosovo Agency of Statistics (KAS 2019). In addition to honey, other products are produced, such as pollen, wax, propolis, bees milk, etc. (MAFRD 2015).

Similarly, Kosovo also imports honey, but there is no standard to check the quality of honey being imported. There is no report on the contamination of honey consumed within the country. Beekeepers commonly apply antibiotics to eliminate disease among honeybees. Researchers revealed that residues of antibiotics in honey are originated mostly from improper beekeeping practices and not from the environment (Forsgren et al. 2010; Johanson et al. 2010; Gajda et al. 2013).

Moreover, some pesticides and veterinary drugs are suspected of causing certain types of cancer, teratogenicity, chromosomal abnormalities, and the weakening of humans' immune system (Banerjee. 1999; McEvoy. 2002; Muhammad et al. 2009; Jeong et al. 2010). Some drugs have the potential to produce toxic reactions in consumers directly. Antibiotics can cause cutaneous eruptions, dermatitis, gastro-intestinal symptoms, and anaphylaxis at very low doses (Gehrig and Warshaw 2008). Antibiotic residues consumed along with honey can produce resistance among bacteria in the consumers, and consequently, there is difficulty in treating many infections in humans (Pyun et al. 2008).

Low dosages of antibiotics used for growth promotion or inappropriate antibiotic prophylaxis in food animals (including bees) for long periods could result in antibiotic-resistant bacteria that can transfer from food to 
humans (Petrović et al. 2008; Asselt et al. 2013). The use of antibiotics in beekeeping is illegal in some European Union (EU) countries. However, there are no maximum residues levels maximum residue levels (MRLs) established for antibiotics in honey according to European Community (EC) regulations, which means that honey containing antibiotics residues are not permitted to be sold (EU 2002). The treatment of honeybees with antibiotics is prohibited in the $\mathrm{EU}$, and there have been significant advances in EU legislation concerning risk assessment. So far, no MRLs have been established for antibiotics and sulfonamides in honey (EU 2010), theoretically meaning that the use of antibiotics by beekeeping is not permitted by European Commission. As stipulated in Annex II of Council Directive, 2001/110/EC (EU 2001), they must, as much as possible, be free from organic or inorganic matter foreign to its composition. EC Directive, 2377/90 with annexes, states that honey should be free from antibiotics contamination (EU 1990), so honey containing these substances cannot be sold in most EU countries, and no MRL of antibiotic residues have been laid down. Some states, like Switzerland, United Kingdom (the UK), and Belgium, have established action limits (level of antibiotics in honey beyond which the sample is deemed non-compliant) for antibiotics in honey, which generally lies between 1.0 to $5.0 \mathrm{ng} / \mathrm{mL}$ for each antibiotic group.

Streptomycin (an antibiotic) is a protein synthesis inhibitor, and despite its toxicity, it is widely used in veterinary medicine for the treatment of aerobic gram-negative bacteria infections (Oliveira et al. 2009; Horie et al. 2004). Streptomycin is commonly used in apiculture for the prophylactic treatment or control of bacterial brood diseases such as European foulbrood and American foulbrood disease (Victoria et al. 2007; Pena et al. 2005). High concentrations of Streptomycin may produce ototoxicity and nephrotoxic effects. However, regular consumption of Streptomycin at low concentrations in foods may also cause allergies, destroy intestinal flora, and cause resistance to certain microorganisms (Cara et al. 2013; Gačić et al. 2015).

\section{Material And Methods}

\section{Samples}

One hundred fifty-five (155) honey samples were collected from different markets (local and imported honey from neighboring countries) and beekeepers in some regions of Kosovo between June and September 2017 (Figure 1).

Sampling was performed according to EU requirements (EU 2006a).

The local honey (131) was provided by the beekeepers of several regions in Kosovo, while imported honey samples (24) were collected from retail markets. All honey samples were labeled either according to their botanical and geographical origin, as suggested by the beekeepers. The samples were stored at room temperature in the dark until analysis. One honey sample was checked to be free of any of the targeted antibiotics, and it was used as blank honey for the calibration curve.

\section{Antibiotic analysis by ELISA}

The determination of Streptomycin was done by Enzyme-Linked Immunosorbent Assay (ELISA) method using I'screen STREPTO test kit (Tecna S. r. I., Trieste, Italy). Analyses were performed according to the test kit's instructions. The procedure is based on the binding of free antibiotics from samples and standard solutions to the anti-streptomycin antibodies during the first incubation. Any unbound substance is removed in a washing 
step. A second incubation is performed with a streptomycin-horseradish peroxidase (streptomycin-HRP) conjugate, which covers all the antibody's remaining free binding sites. The bound enzyme activity is determined by adding a fixed amount of a chromogenic substrate. The enzyme converts the colorless chromogen into a blue product during the third incubation. The addition of the stop reagent leads to a color change from blue to yellow. The absorbance is measured by a microplate reader (Bio-Tek, USA) at $450 \mathrm{~nm}$. The color development is inversely proportional to the streptomycin concentration in the sample. The concentration of Streptomycin was calculated from the calibration curve, which was obtained using six standards with the following concentrations: $0,0.1$, $0.25,1,5$, and 20 nanograms per milliliters $(\mathrm{ng} / \mathrm{mL})$ (Table 1$)$.

Analytical sessions were compliant with assay specifications: Mean B0 absorbance; Binding for the zero standard, maximum binding well (B/BO) 50\% value; calculating and evaluating (CV\%) value related to standard duplicates mean.

In our study, the recovery of streptomycin in spiked honey samples was found to be $84 \%$ (CV = 3.12), $92 \%$ (CV = $1.23)$ and $98 \%(C V=1.03)$ for spiking concentration of $20,80,100 \mathrm{ng} / \mathrm{mL}$, respectively. All experiments were made in triplicate.

\section{Sample preparation}

Streptomycin screening tests were performed at the National Institute of Public Health of Kosovo. The assessments of Streptomycin amounts were conducted using the enzyme immunoassay l'screen STREPTO (Code AB650) $0.0,0.25,1.5,20 \mathrm{ng} / \mathrm{mL}$. The limit of detection (LOD) for Streptomycin is two $2 \mathrm{ng} / \mathrm{mL}$.

Honey samples were prepared according to the manufacturer's instructions, $1 \mathrm{~g}$ of homogeneous honey sample were weighted, then $19 \mathrm{ml}$ of dilution buffer $1 \mathrm{x}$ is added, honey was shaken or vortexed until it is completely dissolved. The sample is filtered with Whatman $\mathrm{N}^{\circ} 1$, and the dilution factor was 20 . Samples were tested immediately after preparation.

\section{Statistical analysis}

Statistical analyses were performed using the Statistical Package for Social Sciences Statistical Package for the Social Sciences (SPSS, USA) software, version 21. The t-test and analysis of variance (ANOVA) were used to assess Streptomycin's differences in honey concentration between the six regions and imported honey samples. The level of significance for the differences was set at Pख0.05; Pख0.01; Pख0.001

\section{Results}

There was a moderate incidence rate of Streptomycin in the local honey with 34 (25.9\%) out of 131 samples positive, while $11(45.8 \%)$ out of 24 imported honey samples were found positive on the Kosovo market as seen in Table 2.

The mean locally produced honey was $2.709 \pm 0.227 \mathrm{ng} / \mathrm{mL}$ and imported honey $2.850 \pm 0.559 \mathrm{ng} / \mathrm{mL}$, respectively.

Most of the positive samples were found in the Ferizaj region (9/42.8\%) with a concentration level of 2.24 - 9.78 and Prizren (13/33\%) with a concentration level of $2.2-6.82$, respectively. In foreign (imported) honey, present on 
the Kosovo market, Streptomycin's frequency was high. Thus 11(45.8\%) out of 24 samples were positive, with a concentration level of 2.2 - 9.8; none of the positive samples were above MRL (Table 3).

The descriptive statistics for the differences in streptomycin concentration in bee honey for the six regions (Gjilan, Mitrovica, Peja, Prizren, Prishtina, and Ferizaj) and imported bee honey determined in this study are shown in Table 4. In a pairwise comparison of the concentration of Streptomycin in bee honey between six regions of Kosovo and imported bee honey, we observed that Prishtina had the highest concentration, followed by Ferizaj, Imported, Prizren, Mitrovica, Peja, and Gjilan. The interval plots presented in Figure 2 offer better visualization of the differences in streptomycin concentrations among the regions.

\section{Discussion}

In our study, Streptomycin was determined in $25.9 \%$ of locally produced honey and $45.8 \%$ of imported honey samples. These results are in parallel with the findings of some previous reports (Ortelli et al. 2004; Baggio et al. 2004; Saridaki-Papakonstadinou et al. 2006; Dugalić-Vrndić et al. 2011; Mahmoudi et al. 2014; Galarin et al. 2015) reported a lower incidence or not detected the antibiotics in honey.

Reybroeck (2003) monitored 248 samples of locally produced and imported honey on the Belgian market for residues of antibiotics in 2000-2001. Streptomycin was detected in 4 (248), tetracycline 2 (72), and sulfonamides in 3 (72) samples. In imported honey, Streptomycin was detected in 51 (102), tetracyclines in 29 (98), sulfonamides in 31 (98), and chloramphenicol 40 (85) samples. Ortelli et al. (2004) analyzed 75 samples in Switzerland (34 originated from Asian countries), of which 13 samples (17\%) contained chloramphenicol residues. In Greece, Saridaki-Papakonstadinou et al. (2006) conducted a survey in which 251 honey samples produced across were analyzed by liquid chromatography to detect tetracycline-derived residues; $29 \%$ of the samples had tetracycline residues. The majority of samples contained residues from 18.0-55.0 ng/mL of honey, while some others had residues in excess of $100.0 \mathrm{ng} / \mathrm{mL}$. Vidal et al. (2009) reported the presence of erythromycin residues in 3 out of 16 samples of honey in Spain by using ultra-performance liquid chromatography-tandem mass spectrometry ultra-performance liquid chromatography-tandem mass spectrometry (UPLC-MS). Gunes et al. (2008) have analyzed 50 honey samples for the possible presence of erythromycin residues in honey collected from the hives in Turkey. The samples were analyzed by liquid chromatography-mass spectrometry using electrospray ionization in the positive ion mode liquid Chromatography-Electrospray lonization-Mass Spectrometry (LC-ESI-MS), and 4 (8\%) of the honey samples were contaminated with erythromycin residues. In Italy, Baggio et al. (2004) have investigated 88 imported honey samples, and 32 out of 88 samples were positive on Streptomycin. Sabatini, Carpana et al. (2003) analyzed Italian honey for the presence of antibiotics whereas they found $2.7 \%$ of tetracycline and 4.5 oxytetracycline residues. Mahmoudi et al. (2014) investigated oxytetracycline residue in 145 honey samples collected from Ardabil provinces, the Northwest region of Iran, by using ELISA and HPLC methods. The ELISA assay showed that 34 out of 145 samples were positive while the minimum and maximum oxytetracycline residue levels were 5.32 and $369.1 \mathrm{ng} / \mathrm{mL}$, respectively. There are few reports of antibiotics in honey in neighboring countries as Serbia and Bosnia and Herzegovina. Thus, Dugalić- Vrndić et al. (2005) determined the antibiotics and sulphonamides residues in 100 honey samples from Belgrade market and supermarket. In total, 18 samples were found positive. In contrast, Dugalić-Vrndić et al. (2011) tested 65 honey samples and found residues of antibiotics and sulfonamide in 8 samples. Apić et al. (2015) examined 193 honey samples in Vojvodina. The presence of antibiotic residues in honey resulted in 5 out of 193 tested honey samples. Mujić et al. (2011) researched the 
presence of antibiotic residues in 46 honey samples, whereby no concentrations of antibiotics and sulfonamides were found.

In the work of Galarin et al. (2015), 74 honey samples were collected in the Italian market, and nine or (12\%) samples were found positive on sulfonamides.

Bonerbaa et al. (2021) examined 98 honey samples for Streptomycin during 2018-2019 in Italy's different regions. The presence of Streptomycin resulted in 33 out of 98 tested honey samples.

In another study, Kokmaz et al. (2017), using the ELISA technique, 59 samples were tested for the possible presence of Streptomycin and sulfonamides. Thus, 35 or (59\%) samples were found positive on Streptomycin, with a level of 6-42 ng/ml, and 31 (53\%) positive samples on sulfonamide, at a level of 3-32 ng/ml.

\section{Conclusions}

The present investigation is the first research performed in Kosovo to evaluate the presence of antibiotic residues in foodstuffs, and in particular, bee honey. In our validation tests, we spiked honey samples at the level of 5 ppb of Streptomycin, and we obtained a sensitivity of $97.5 \%$. That means that $97,5 \%$ of samples are dosed as positives. Usually, that value has been reported as C Cbeta (EU, 2002; 2010). Moreover, the difference in B/Bo\% of spiked samples vs negative samples is $21 \mathrm{~B} / \mathrm{Bo} \%$ points of difference.

Our results indicate the presence of Streptomycin in honey intended for human consumption in Kosovo. The considerable levels of residues detected in honey, although regionally limited, are a human health concern that prompts several recommendations addressed to public authorities, veterinarians, honeybee producers, and consumers. In addition to implementing appropriate regulatory legislation and providing an adequately controlled sampling network, we should be able to provide effective means for food control with proper risk assessments that will instill confidence in consumers. Competent authorities should establish and maintain continuous monitoring programs to ensure risk-free honey and its products to Kosovo consumers. Besides, there is a pressing need for additional research to accurately assess other aspects of this problem and identify effective corrective actions that are designed to reduce honey contaminants.

\section{Abbreviations}

1. ELISA-Enzyme-linked receptor-binding assays;

2. MRL-Maximum residue levels;

3. $\mathrm{ng} / \mathrm{mL}$. - Nanograms per milliliters

4. UE- European Union;

5. MAFRD- Ministry of Agriculture, Forestry and Rural Development;

6. KAS- Kosovo Agency of Statistics;

7. EC- European Commission;

8. UK- United Kingdom;

9. Streptomycin-HRP-Streptomycin-horseradish peroxidase

10. USA- United States of America; 
11. CV\% - Calculating and evaluating;

12. LOD- The limit of detection;

13. SPSS- Statistical Package for the Social Sciences;

14. ANOVA-Analysis of Variance;

15. UPLC-MS. Ultra-performance liquid chromatography-tandem mass spectrometry;

16. LC-ESI-MS - Liquid Chromatography-Electrospray lonization-Mass Spectrometry;

17. HPLC- High-performance liquid chromatography;

18. B/Bo\%-Binding for the zero standard, maximum binding well;

\section{Declarations}

\section{- Availability of data and materials}

Not applicable

\section{-Competing interests}

Not applicable

- Funding

This work was financially supported by the Ministry of Education, Science, and Technology of Kosovo as a small research project for science and technology development (2-2109).

\section{- Authors' contributions}

A. R. and I. H. wrote the main manuscript text and figures; I. M. prepared statistical data and A. Z, B. ZH, A. L, D. H, F. L. assisted by laboratory analysis. All authors reviewed the manuscript.

\section{- Acknowledgements}

Not applicable

\section{References}

1. J Ljubojević D, Prica N, Jakšić S, Ratajac R, Babić J, Živko-Balo M (2015) Antibiotic residues in honey samples collected within a year in AP Vojvodina, Serbia. J. Agric. Sci 64(3-4):262-267.

2. Asselt ED, Spiegel M, Noordam MY, Pikkemaat MG, Fels-Klerx HJ (2013) Risk ranking of chemical hazards in food A case study on antibiotics in the Netherlands. Food Res. Int 54(2):1636-1642. https://doi.org/10.1016/j.foodres.2013.08.042

3. Baggio A, Gallina A, Benetti C, Dainese N, Manzinello C, Piro R, Mutinelli F (2004). Official control on imported honey in north-eastern Italy. Apiacta 39:5-7.

4. Banerjee BD (1999) The influence of various factors on immune toxicity assessment of pesticide chemicals. Toxicol. Lett 107(1-3):21-31. https://doi.org/10.1016/S0378-4274_(99)ㅁ00028-4 
5. Bonerbaa E, Panserib S, Ariolib F, Nobileb M, Terioa V, Di Cesareb F, Tantilloc G Chiesa L (2021)

Determination of antibiotic residues in honey in relation to different potential sources and relevance for food inspection. Food Chem 334(1):1-9. https://doi.org/10.1016/j.foodchem.2020.127575

6. Cara MC, Dumitrel G, Glevitzky M, Mischie C, Silaghi-Perju D (2013). Thermal degradation of streptomycin residues in honey during storage. Food Technol. Biotechnol 51(3):429-433.

7. Dugalić- Vrndić N, Mladenović M, Nedić N (2005) Antibiotic and sulphonamide residues in honey from Belgrade market AGRIS: International Information System for the J. Agric. Sci. Technol. (p 53-56), Beograd Serbia. http://agris.fao.org/agris-search/search.do?recordID=CS2005001022

8. Dugalić-Vrndić N, Kečkeš J, Mladenović M (2011) The authenticity of honey in relation to quality parameters. Biotechnol. Anim. Husb. 27(4):1771-1778. https://doi.org/10.2298/BAH1104771D

9. European Union. (1990). Directive 2377/37/90 of the European Parliament and of the Council of 26 June 1990 laying down a community procedure for the establishment of maximum residue limits of veterinary medicinal products in foodstuffs of animal origin. Off J Eur. Page (L224): 1-

8. https://ec.europa.eu/health//sites/health/files/files/eudralex/vol5/reg_1990_2377/reg_1990_2377_en.pdf

10. European Union. (2001). Directive 657/2002 the European Parliament and of the Council of 20 December 2001 relating to honey. 24. Off J Eur Comm. Page (L10): 47-

52.https://www.wipo.int/edocs/lexdocs/laws/en/eu/eu159en.pdf

11. European Union. (2002). Directive 657/2002 the European Parliament and of the Council of 12 August 2002 implementing Council Directive 96/23/EC concerning the performance of analytical methods and the interpretation of results. Off J Eur Comm. Page (L221): 8-236.

https://eurlex.europa.eu/LexUriServ/LexUriServ.do?uri=OJ:L:2002:221:0008:0036:EN:PDF

12. European Union. (2006a). Directive 1881/2006 the European Parliament and of the Council of 19 December 2006 setting maximum levels for certain contaminants in foodstuffs. Off J Eur Comm. Page (L364): 5-24. http://www.megapesca.com/eu_regulations_update/EC_No_1881_2006_19_December_2006.pdf

13. European Union. (2010). Directive 2010/37/EC of the European Parliament and of the Council of 22 December 2009 on pharmacologically active substances and their classification regarding maximum residue limits. 24. Off J Eur Comm. Page (L15):1-72. https://eurlex.europa.eu/LexUriServ/LexUriServ.do? uri=OJ:L:2010:015:0001:0072:EN:PDF

14. Forsgren E, Olofsson TC, Váasquez A, Fries I (2010) Novel lactic acid bacteria inhibiting Paenibacillus larvae in honey bee larvae. Apidologie 41(1):99-108. https://doi.org/10.1051/apido/2009065

15. Gačić M, Bilandžić N, Šipušić Đ I, Petrović M, Kos B, Vahčić N, Šušković J (2015) Degradation of oxytetracycline, streptomycin, sulphathiazole and chloramphenicol residues in different types of honey. Food Technol. Biotechnol 53(2):154-162. https://doi.org/10.17113/ftb.53.02.15.3934

16. Gajda A, Posyniak A, Bober A, Bladek T, Zmudzki J (2013) Oxytetracycline Residues in Honey Analyzed by Liquid Chromatography with UV Detection. J Apic Sci 57(1):25-32. https://doi.org/10.2478/jas-2013-0003

17. Galarini R, Saluti G, Giusepponi D, Rossi R Moretti S (2015) Multiclass determination of 27 antibiotics in honey. Food Control 48:12-24. https://doi.org/10.1016/j.foodcont.2014.03.048

18. Gehrig KA, Warshaw EM (2008) Allergic contact dermatitis to topical antibiotics: Epidemiology, responsible allergens, and management. J. Am. Acad. Dermatol 58(1):1-21. https://doi.org/10.1016/j.jaad.2007.07.050

19. Gunes N, Cibik R, Gunes ME, Aydin L (2008) Erythromycin residue in honey from the Southern Marmara region of Turkey. Food Addit. Contam: Part A 25(11):1313-1317. 
https://doi.org/10.1080/02652030802233472

20. Horie M, Saito H, Natori T, Nagata J, Nakazawa H (2004) Determination of Streptomycin and dihydrostreptomycin in honey by liquid chromatography-electrospray mass spectrometry. J. Liq. Chromatogr. Relat. Technol 27(5):863-874. https://doi.org/10.1081/JLC-120029703

21. Jeong SH, Kang D, Lim MW, Kang CS, Sung HJ (2010) Risk Assessment of Growth Hormones and Antimicrobial Residues in Meat. Toxicol. Res 26(4):301-313. https://doi.org/10.5487/TR.2010.26.4.301

22. Johanson S, Jadon N, Mathur HB, Agarwal HC (2010). Antibiotic Residues in Honey. September 2010. https://www.academia.edu/1386654/Antibiotic_Residues_in_Honey

23. Korkmaz, SD., Kuplulu, O., Cil, GI \& A, E. (2017). Detection of Sulfonamide and Tetracycline Antibiotic Residues in Turkish Pine Honey. Int. J. Food Prop 20(1):S50-S55.

https://doi.org/10.1080/10942912.2017.1288135

24. KAS. Kosovo Agency of Statistics. (2019). Statistical yearbook. Prishtina. https://ask.rksgov.net/media/5082/vjetari-2019_ang-final.pdf

25. Mafrd. (2015). Green Report. The Ministry of Agriculture Forestry and Rural Development, Prishtine. https://www.mbpzhrks.net/repository/docs/Green_Report_Kosovo_2015_Eng_final.pdfMahmoudi R, Moosavy MH, Norian R, Kazemi S, Nadari MRA, Mardani K (2014) Detection of oxytetracycline residues in honey samples using ELISA and HPLC methods. J Pharm Sci 19(4):145-150.

26. McEvoy JDG (2002) Contamination of animal feedingstuffs as a cause of residues in food: a review of regulatory aspects, incidence, and control. Anal. Chim. Acta 437(1-2):3-26. https://doi.org/10.1016/S00032670(02)00751-1

27. MAFRD. Ministry of Agriculture, Forestry and Rural Development. (2017) Analiza e tregut te mjaltes. https://www.mbpzhr-ks.net/repository/docs/19062017_Analiza_e_tregut_te_mjaliti.pdf

28. Muhammad F, Akhtar M, Zia-ur-Rahman, Javed I, Anwar MI (2009) Role of Veterinarians in Providing Residue-Free Animal Food. Pak. Vet. J 29(1):42-46.

29. Mujić I, Alibabic V, Jokic S, Galijasevic E, Jukic D, Bajramovic M (2011) Determination of Pesticides, Heavy Metals, Radioactive Substances, and Antibiotic Residues in Honey. Pol. J. Environ. Stud 20(3):719-724.

30. Oliveira RCD, Paschoal JAR, Sismotto M, Airoldi F PDS, Reyes FGR(2009). Development and validation of an LC-APCI-MS-MS analytical method for the determination of streptomycin and dihydrostreptomycin residues in milk. J. Chromatogr. Sci 47(9):756-761. https://doi.org/10.1093/chromsci/47.9.756

31. Ortelli D, Edder P, Corvi C (2004) Analysis of chloramphenicol residues in honey by liquid chromatographytandem mass spectrometry. Chromatographia 59(1):61-64.

32. Panettieri V (2013) Report of the mision in Kosovo. International Link and Services for Local Economic Development Agencies. http://www.ilsleda.org/usr_files/documents/kosovo2013_beesreport01_740222.pdf

33. Pena A, Pelantova N, Lino CM, Silveira MIN, Solich P (2005) Validation of an analytical methodology for determination of oxytetracycline and tetracycline residues in honey by HPLC with fluorescence detection. J. Agric. Food Chem 53(10):3784-3788. https://doi.org/10.1021/jf050065r

34. Petrović J, Milanov D, Ratajac R (2008) Contemporary food safety trends: Antimicrobial resistance in zoonotic pathogens. Vet. Glas 62(5-6): 373-382. https://doi.org/10.2298/VETGL0806373P

35. Pyun CW, Abd El-Aty AM, Hashim MM, Shim JH, Lee SK, Choi KD, Lee C(2008) Monitoring of streptomycin and dihydrostreptomycin residual levels in porcine meat press juice and muscle via solid phase fluorescence 
immunoassay and confirmatory analysis by liquid chromatography after post column derivatization. Biomed. Chromatogr 22(3):254-259. https://doi.org/10.1002/bmc.920+

36. Reybroeck W (2003) Residues of antibiotics and sulfonamides in honey on the Belgian market. Apiacta 38: 23-30.

37. Sabatini AG, Carpana E, Serra G, Colombo R (2003) Presence of acaricides and antibiotics in samples of Italian honey. Apiacta 38:46-49.

38. Saridaki-Papakonstadinou M, Andredakis S, Burriel A, Tsachev I (2006) Determination of tetracycline residues in Greek honey. Trakia J. Sci 4(1):33-36.

39. Victoria B, Marghitas LA, Dezmirean D, Moise A, Bobis O, Maghear O(2007) Optimization of HPLC method for quantifying tetracycline residue in honey. Bulletin of the University of Agricultural Sciences and Veterinary Medicine Cluj-Napoca. J. Anim. Sci. Biotechnol 63(1-2):186-190. http://dx.doi.org/10.15835/buasvmcnasb:64:1-2:2195

40. Vidal JL, Aguilera-Luiz MM, Romero-González R, Frenich AG (2009) Multiclass analysis of antibiotic residues in honey by ultra-performance liquid chromatography-tandem mass spectrometry. J. Agric. Food Chem 57(5):1760-1767. https://doi.org/10.1021/jf8034572

\section{Tables}

Table 1. Obtained reference values of I'screen STREPTO

\begin{tabular}{|lllllll|}
\hline & Std 1 & Std 2 & Std 3 & Std 4 & Std 5 & Std 6 \\
\hline Conct. (ng/mL) & 0.0 & 0.1 & 0.25 & 1 & 5 & 20 \\
\hline B/B & 100.0 & 83.0 & 70.8 & 47.6 & 23.8 & 13.7 \\
\hline
\end{tabular}

Table 2. Occurrence of streptomycin antibiotic in commercial honey in Kosovo during 2017

\begin{tabular}{|lllll|}
\hline Honey & $\begin{array}{l}\text { No. Of } \\
\text { Samples }\end{array}$ & $\begin{array}{l}\text { No. Of positive } \\
\text { Samples }\end{array}$ & $\begin{array}{l}\text { No. Of negative } \\
\text { Samples }\end{array}$ & $\begin{array}{l}\text { Positive samples } \\
\text { Mean } \pm \text { SD }\end{array}$ \\
\hline Local & 131 & $34(25.9 \%)$ & $97(74.1 \%)$ & $2.709 \pm 0.227$ \\
\hline Imported & 24 & $11(45.8 \%)$ & $13(54.2 \%)$ & $2.850 \pm 0.559$ \\
\hline Total & 155 & $45(29 \%)$ & $110(71 \%)$ & $2.731 \pm 0.210$ \\
\hline
\end{tabular}

Table 3. Distributions by regions of positive samples and concentration levels $(\mathrm{ng} / \mathrm{mL})$ in locally and imported honey during 2017 


\begin{tabular}{|llll|}
\hline Regions & $\begin{array}{l}\text { Total } \\
\text { samples }\end{array}$ & $\begin{array}{l}\text { Positive } \\
\text { samples } \\
\mathbf{n}(\%)\end{array}$ & $\begin{array}{l}\text { Lower and upper Streptomycin contamination level } \\
(\mathbf{n g} / \mathrm{mL})\end{array}$ \\
\hline Local & & $2(9.1)$ & $6.92-9.32$ \\
\hline Gjilan & 22 & $3(17.6)$ & $2.31-5.78$ \\
\hline Mitrovica & 17 & $4(20)$ & $2.1-5.3$ \\
\hline Peja & 20 & $13(33.3)$ & $2.2-6.82$ \\
\hline Prizren & 39 & $3(25)$ & $4.38-8.78$ \\
\hline Prishtina & 12 & $9(42.8)$ & $2.24-9.78$ \\
\hline Ferizaj & 21 & $11(45.8)$ & $2.2-9.8$ \\
\hline Imported & 24 & $45(29.0)$ & $2.1-9.8$ \\
\hline Total & 155 & & \\
\hline
\end{tabular}

Table 4. The differences in streptomycine concentration among the regions included in the study 


\begin{tabular}{|c|c|c|c|c|c|}
\hline \multicolumn{6}{|l|}{ Regions } \\
\hline \multirow{6}{*}{$\begin{array}{l}r_{1} \\
(n=22)\end{array}$} & r2-rt1 & 1.39 & 0.77 & 1.81 & 0.073 \\
\hline & r3-r1 & 0.17 & 0.74 & 0.23 & 0.816 \\
\hline & $r 4-r 1$ & 1.82 & 0.64 & 2.86 & 0.005 \\
\hline & r5-r1 & 5.56 & 0.86 & 6.49 & 0.000 \\
\hline & r6-r1 & 4.79 & 0.73 & 6.58 & 0.000 \\
\hline & r7-r1 & 2.021 & 0.70 & 2.87 & 0.005 \\
\hline \multirow{5}{*}{$\begin{array}{l}r_{2} \\
(n=17)\end{array}$} & r3-r2 & 1.22 & 0.79 & 1.55 & 0.124 \\
\hline & r4-r2 & 0.43 & 0.69 & 0.62 & 0.537 \\
\hline & r5-r2 & 4.17 & 0.90 & 4.63 & 0.000 \\
\hline & r6-r2 & 3.40 & 0.78 & 4.37 & 0.000 \\
\hline & r7-r1 & 0.63 & 0.76 & 0.83 & 0.408 \\
\hline \multirow{4}{*}{$\begin{array}{l}r_{3} \\
(n=20)\end{array}$} & r4-r3 & 1.65 & 0.66 & 2.51 & 0.013 \\
\hline & r5-r3 & 5.39 & 0.87 & 6.18 & 0.000 \\
\hline & r6-r3 & 4.62 & 0.75 & 6.19 & 0.000 \\
\hline & r7-r3 & 1.85 & 0.72 & 2.56 & 0.012 \\
\hline \multirow{3}{*}{$\begin{array}{l}r_{4} \\
(n=39)\end{array}$} & r5-r4 & 3.74 & 3.79 & 4.74 & 0.000 \\
\hline & r6-r4 & 2.97 & 0.65 & 4.60 & 0.000 \\
\hline & r7-r4 & 0.20 & 0.62 & 0.32 & 0.749 \\
\hline \multirow{2}{*}{$\begin{array}{l}r_{5} \\
(n=12)\end{array}$} & r6-r5 & 0.76 & 0.86 & 0.89 & 0.377 \\
\hline & r7-r5 & 3.54 & 0.84 & 4.19 & 0.000 \\
\hline $\begin{array}{l}r_{6} \\
(n=21)\end{array}$ & r7-r6 & 2.77 & 0.14 & 3.89 & 0.000 \\
\hline
\end{tabular}

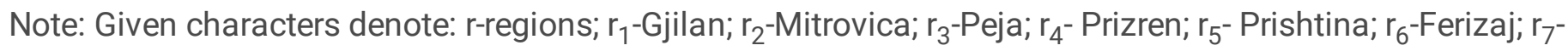

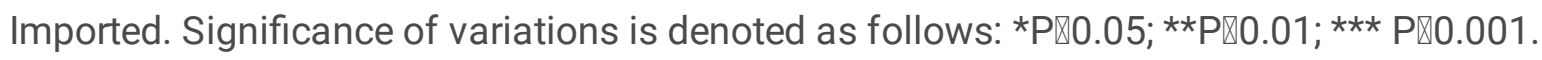

\section{Figures}




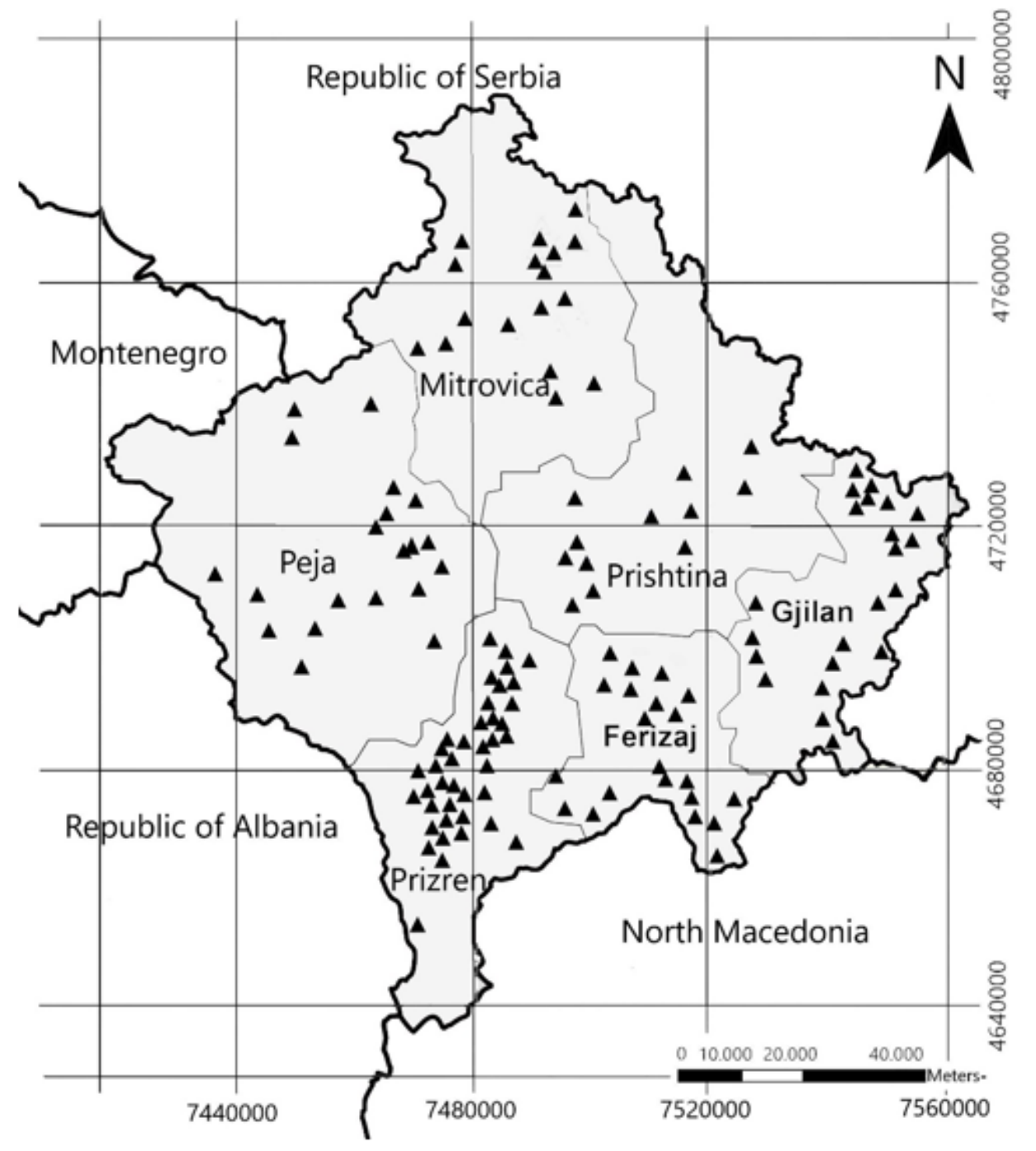

Figure 1

Sample collection sites in six regions of Kosovo: Gjilan, Mitrovica, Peja, Prizren, Prishtina, and Ferizaj.
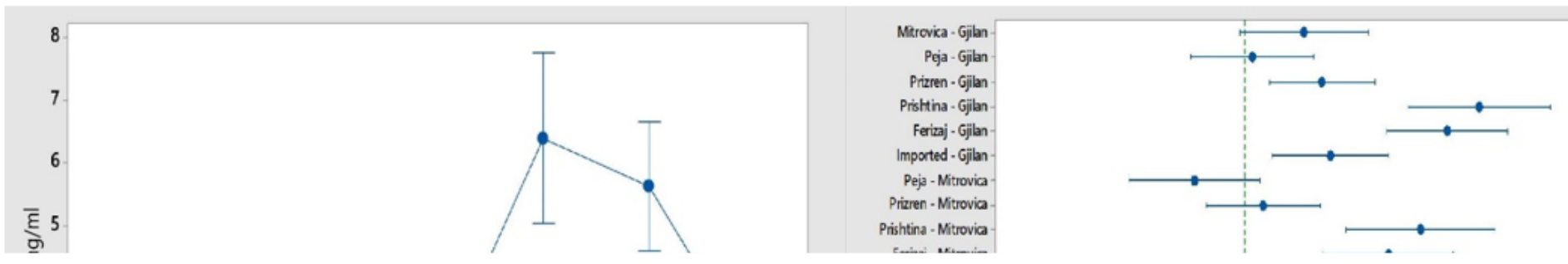
Figure 2

Interval plots of Streptomycin in local and imported bee honey 